month. No interference was neceseary, and nothing occurred to lead to the diagnosis of the abnormality on either of these occasions. The patient first menstruated at the age of thirteen years, and the catamenia have always been regular and rather profuse. All three pregnancies have been attended thronghout by complete amenorrhoa. The pelvis showed no increase in width, such as has been noticed in some cases of double uterus. The promontory of the sacrum was somewhat prominent, and there was some contraction of the conjugate diameter of the brim, without, however, those changes in the external measurements characteristic of the rachitic flattened pelvis. The measurements were : diagonal conjugate, $4 \frac{1}{4}$ inches; distance of iliac crests, $10 \frac{1}{2}$ inches; distance of iliac spines, $9 \frac{1}{2}$ inches. Our best thanks are due to Dr. Cullingworth and Dr. Cory for permission to publish this case.

\section{REMARKABLE CASE OF PERFORATION OF EYEBALL.}

BY H. A. BRYANT, M.R.C.S. ENG. \&c.,

RESLENT MEDICAL OFFICER, COUNTY HOSPITAL, DURHAM.

ON April 3rd a man twenty-one years of age attended the Durham County Hospital with the history that, while walking beside his cart with a friend, he was suddenly struck with something in the right eye, causing him intense pain and loss of sight. On examining him I found a lacerated perforating woond the size of a hemp seed about three-sixteenths of an inch from the outer margin of the cornea, ont of which some of the vitreous was escaping. The conjunctiva was congested, there were blood in the lower half of the anterior chamber, but not blocking up the pupil, loss of tension, and sinking in of the iris and lens. Loss of sight both for light and objects was complete. Ophthalmoscopic examination conld detect nothing, no reflex being present, and no foreign body could be seen with focal illamination. About four hours after the accident the man was put under chloroform, and I passed a probe into the wound for about an inch in a downward, backward, and inward direction, encountering what seemed to me to be some soft foreign body. As it could not be removed the eyeball was enucleated. On examining the eye afterwards, embedded in the back part of the vitreous a knot of whipcord, evidently from the end of a whip, was found, which must have penetrated the globe and passed through the vitreous. The lens was uninjured. The patient made a good recovery, and left the hospital seven days after the operation. On questioning him be was quite at a loss as to how the accident could have occurred, declaring that his own whip was in the cart, and that no one anywhere near was Aidosing one about. The case is that of an accident which almost everyone is liable to, and it shows what considerable force there is in a flick of a whip which can penetrate such a tough body as an eyeball.

\section{DISLOCATION OF THE LOWER JAW DURING AN EPILEPTIC FIT.}

BI CRCIL F. BEADLES, M.R.C.S. ENG., I.R.C.P. LOND, ASSISTANT MEDICAL OFFICER, LONDON COUXTY ASTLUM, COLNEY HATCH.

A CASE of dislocation of the lower jaw during an epileptic fit is such a rare event that the following is worthy of being iecorded. It occurred in a youth aged twenty who had been an inmate of Colney Hatch Asylum about two years and a balf. He is the subject of chronic mania, with delusions, is often excited and quarrelsome, and has frequent epileptic fits, occurring more especially during the night, but which interfere bat little with his employment on the grounds during the day. He has a somewhat imbecile expression, with a peculiar, hesitating, slow manner of speech ; moreover, his lower jaw has the appearance of being rather loosely articulated. Dislocation of the right condyle occurred during the night while the patient was in a severe fit, and its reduction was effected without difficulty when he recovered from it. I have been unable to discover that this rare event has previously happened in this asylum, although some years ago there were two male patients who could put their jaws out and replace them with ease; neither of these was epileptic. Fitichsen does not mention epileptic fits as a cause of this variety of dislocation.

\section{A cettirux}

\section{H O S P I T A L P R A C T I C E BRITISH AND FOREIGN.}

Nulla autem est alia pro certo noscendi via, nisi quamplurimas et mor borum et dissectionum historias, tum aliorum tum proprias collecta habere, et inter se comparare.-Morgagni De Scd. et Caus. Morb. lib. iv. Procemium.

\section{ROYAL BERKSHIRE HOSPTTAL.}

CASE OF DOUBLE BASIC PNEUMONIA ASFOUIAEOD WITH PRISGNANCY, HEART DISEASE, AND BRONCEI'IS, AND FOLLOWED BY EMPYEMA; RESECIION OE RIBS RECOVERY ; REMARKS.

(Cnder the care of Dr. Francis HAwkINs.)

THERE is no doubt that pneumonia is one of the most serious complications of pregnancy, and although several cases are on record where the patient has recovered, its onset is rightly regarded with great anxiety by the physician. Dr. Rendu ${ }^{l}$ has in a clinical lecture devoted to this subject entered fully into a consideration of it. That the disease is aggravated by pregnancy is proved by statistics, which show a mortality of 8 to 9 per cent. He further states that the more advanced the pregnancy the graver the pnenmonia, the cause of this being partly mechanical, from diminution of bæmatosis; but, in addition, the heart at this period is already fatigued, and the kidneys to a certain extent altered by pregnancy, thus bringing about a serious pathological condition. The frequency of abortion, which aggravates the situation, appears to be due to the fact that the foetus dies from infection, and the uterus hastens to free itself. Dr. Rendu considers that abortion renders the patient's state more serious, and that dangerous symptoms are apt to develop very rapidly after it. This case, it will be noted, was apparently less fitted than usual to cope with the disease on account of the cardiac affection.

A woman aged thirty-five years was admitted to the Royal Berkshire Hospital on April 5th, 1894, complaining of pain in the left side, cough, and slight expectoration, all of which had commenced suddenly three days before and were not preceded by shivering or vomiting. The thoraz, which was well formed, moved but slightly on the left side during inspiration. The physical signs on this side were slight vocal fremitus, absolute dulness over the infrascapular region, marked dulness over the lower part of the inter-scapular and over the whole of the infra-axillary regions, the breath sounds tubalar in character over all the above regions, a small amount of fine crepitation, and a great increase of vocal resonance. On the right side there were no abnormal physical signs. The first cardiac sound was decidedly impure, but there was no absolute murmur. The temperature was $99.6^{\circ} \mathrm{F}$. and the pulse 108 . The patient was at about the fourth month of pregnancy. On April 7th pain was felt in the right side of the chest, which now moved less freely in respiration, and over the infrascapular region there was dulness with tubular breathing. The highest temperature (at $3 \mathrm{~A} . \mathrm{M}$.) was $102.5^{\circ}$; the pulse was 128. On the 9 th the general condition of the patient was very bad, the dyspncea being very marked and the lower lip cyanosed. The signs of consolidation of both bases were still present. The highest temperature (at 3 P.M.) was $102 \cdot 6^{\circ}$, the pulse was 132 , and the respiration 55 . Liquor strychnix was given every four hours. On the 10th the dyspnoea was less and the lower lip was not cyanosed. The highest temperature (at 11 A.M.) was $100.8^{\circ}$ and the lowest was $986^{\circ}$. The pulse was 120 and the respiration 50. On the 11th, which was the day of crisis, or ninth day of the disease, the temperature in the forenoon was $98^{\circ}$ and the general symptoms were rather less urgent. At 10 P.M., however, there was severe dyspnoea with constant hacking cough, and the pulse rose to 130 . Digitalis and ammonia were now administered. (At first the patient was ordered brandy, which she took till the 10 th, when port wine was substituted.) On the 15th the patient was not so well and complained of pain in the right posterior axillary line ; there

Journal de Médecine et de Chirurgie Pratique, Paris, vol. i. 1893. Sajous' Annual of the Universal Medical Sciences, vol. ii., 1894, if. 13. 